\title{
Determinants of Debt Policy for Public Companies in Indonesia
}

\author{
Hasan MUKHIBAD ${ }^{1}$, Subowo SUBOWO ${ }^{2}$, Denis Opi MAHARIN ${ }^{3}$, Saparuddin MUKHTAR ${ }^{4}$ \\ Received: April 01, 2020 Revised: April 17, 2020 Accepted: May 07, 2020
}

\begin{abstract}
This research seeks to determine the influence of investment opportunity set (IOS); profitability (Return on Assets - ROA), liquidity, business risk and firm size on debt policy. We used 42 manufacturing companies registered on the Indonesian Stock Exchange (Bursa Efek Indonesia) as object research. We used purposive sampling method to determined samples, consider the period observation from 2012 to 2016, and produce 168 units analysis. Data analysis uses the multiple regressions with the SPSS tools. The results of the study found that companies' debt policies in Indonesia are negatively affected by the liquidity. Investment opportunity set (IOS) has negative effect on debt policy. Meanwhile, ROA, Return on Invested Capital (ROIC), and firm size of a company has no impact on debt policy. These findings indicate that Indonesian manufacture companies do not see the high investment opportunity set and profitability as a policy basis for increasing debt. Moreover, the high profitability also does not cause companies to increase their debt ratio. Our study indicates that Indonesian manufacture companies use internal funds to fund their investment. This finding is a concern for creditors, as they can now see the ability of the companies, and especially their performance, in determining their credit policies.
\end{abstract}

Keywords : Business Risk, Investment Opportunity Set, Profitability, Liquidity; Manufacture Companies, Firm Size

JEL Classification Code: M41, G23, G32

\section{Introduction}

The Indonesian economy is currently improving. One of the indicators to measure the performance of the economy is gross domestic product (GDP). Indonesia's GDP has shown a steady increase over the last 10 years. This ever-increasing economic growth creates the potential for companies to increase the scale of their businesses. Companies can use funding sources that come from capital or debt, to realize

${ }^{1}$ First Author and Corresponding Author. Accounting Department, Faculty of Economics, Universitas Negeri Semarang, Indonesia [Postal Address: 50229. Kampus Sekaran, Gunungpati, Semarang City, Jawa Tengah, Indonesia]

Email: hasanmukhibad@mail.unnes.ac.id

${ }^{2}$ Accounting Department, Faculty of Economics, Universitas Negeri Semarang, Indonesia. Email: subowo@mail.unnes.ac.id

${ }^{3}$ Accounting Department, Faculty of Economics, Universitas Negeri Semarang, Indonesia. Email: denisopimaharin169@gmail.com

${ }^{4}$ Economics Education Department, Faculty of Economics, Universitas Negeri Jakarta, Indonesia. Email: saparuddin@unj.ac.id

(c) Copyright: The Author(s)

This is an Open Access article distributed under the terms of the Creative Commons Attribution Non-Commercial License (http://Creativecommons.org/licenses/by-nc/4.0/) which permits unrestricted noncommercial use, distribution, and reproduction in any medium, provided the original work is properly cited. this increase in their businesses. This means that there is a tendency for an increase in the companies' debt, due to an increase in the economy (Gajurel, 2011; Buvanendra, Sridharan and Thiyagarajan, 2016; Rodrigues et al., 2017; Bokpin, 2009; Mahmud, 2003). Therefore, capital structure is one of the important policies for management in the corporate financial management (Nguyen, Bui, \& Pham, 2019; Nguyen \& Nguyen, 2020).

This also applies in Indonesia. In the second quarter of 2017, there were 19 companies that issued bonds (Maulana, 2017). In 2018, the Indonesian Stock Exchange recorded that seven companies were planning to issue debt obligations in the form of bonds and sukuk, with a total value of 13.76 trillion Rp (Wareza, 2018). The President Director of the Indonesian Securities Rating Agency (PEFINDO) stated that the majority of the bond issuances were by banking and corporate financing companies. However, starting in 2017, the portion of the non-financial sector that issued bonds increased. This condition does not improve investors' trust toward companies in Indonesia. Moody's report titled "Risks from Leveraged Corporates Grow as Macroeconomic Conditions Worsen" revealed that Indonesia and India are two of 13 countries in the Asia Pacific region that have the highest risk of default (Osmorsa, 2019). This means that 
companies in Indonesia have the potential to fail to make their debt payments.

The proof of this statement is the failure to pay by the Transindo Taxi Express Company, which caused its bond rating to decrease from $\mathrm{BB}$ to $\mathrm{D}$. Also failing to meet their debt payments were PT. Tiga Pilar Sejahtera Food Tbk., PT. Sariwangi Agricultural Estate Agency (SAEA), PT. Sunprima Nusantara Financing (SNP Finance), PT. Asuransi Jiwasraya, PT. Kawasan Industri Jababeka Tbk., (KIJA) and PT. Delta Merlin Dunia Textile (DMDT) (Sugianto, 2019). This requires companies to pay attention to, and to evaluate, their ability to repay any debt they enter into.

The importance of debt policy is the reason researchers link debt policy and performance (Nguyen \& Nguyen, 2020) and result findings are mixed (Qayyum \& Noreen, 2019). Kyissima, Xue and Abeid (2019); Tailab (2014); Desmintari and Yetty (2015); Haron (2016); and Vătavu (2015) find that company performance has a negative effect on debt ratio. Meanwhile, Serghiescu and Vaidean (2014); Murtiningtyas (2012); and Panda and Nanda (2018) find that debt ratios have a positive influence on company performance.

Scholars also use Investment Opportunity as a factor affecting debt policy. However, the conclusion of the relationship between IOS and debt policy is inconsistent. Dalbor and Upneja (2004) identify growth opportunities as proxies for explaining debt policy for firms. Fitriyah and Hidayat (2011); Skinner (1993); Dalbor and Upneja (2004); Hikmah et al. (2019); and Surya and Rahayuningsih (2012) show that the results of the Investment Opportunity Set (IOS) have a significant negative effect on debt. However, Marfuah (2014); Dalbor and Upneja (2004), and Nguyen et al. (2019) found a positive relationship between IOS and debt.

The mixed findings of previous research are the reason for conducting this research. We focus on firms in Indonesia because Indonesia has a high investment risk. In addition, Indonesia is a developing country, and has a large investment potential (Osmorsa, 2019). The focus of our study is manufacturing firms, because this sector has a high impact on Indonesia's economic growth (Handriani \& Robiyanto, 2018).

\section{Literature Review}

This research is based on the pecking order theory, the trade-off theory, and the signaling theory. The pecking order theory states that when a company needs sources of funding for its activities, the first thing selected and used is the company's internal funds, then debt, and the last one is issuing more shares, based on the increasing risks involved (Abdullah \& Pok, 2015; Gómez et al., 2015). According to the pecking order theory, companies consider that the use of debt has a smaller risk than raising funds by a new stock issuance (Narita, 2012). The trade-off theory explains that a company's capital structure is determined by the balance of its strengths and weaknesses that arise due to the use of debt (Surya \& Rahayuningsih, 2012; Salehi et al., 2017). The signaling theory talks about managements' actions giving clues or information to external parties about a company's condition (Karina \& Khafid, 2015).

An increasingly good level of profitability is a sign that a company is experiencing growth. Growing companies maximize the opportunities that exist to continue to grow. The goal of a growing company is to increase its profits or earnings. An increase in profits will result in an increase in internal funds, so that these funds can be used as a source of corporate funding. Profitability is used to assess the company's efforts to make a profit (Utama \& Khafid, 2015). Companies with high profits will take on less debt (Narita, 2012; Surya \& Rahayuningsih, 2012; Natasia \& Wahidahwati, 2015).

Our data show that a decline in profitability is followed by an increase in debt. Companies with high profitability generate large cash flows and as a result, sufficient net income to be used as a source of internal financing (Jóźwiak, Marszalek, \& Sekula, 2015). Based on the pecking order theory, there is a sequence for making funding decisions. The main priority is retained earnings, then debt, and subsequently stock issues. If profitability is low, then the company will borrow funds from external parties. Based on the lowest level of risk, which is debt, then the company will select debt as an external funding source. This is in line with research conducted by Murtiningtyas (2012), Surya and Rahayuningsih (2012), Desmintari and Yetty (2015), Natasia and Wahidahwati (2015); Purwohandoko, (2017) and Haron (2016) who all found that profitability has a negative influence on debt policy. The first hypothesis, based on the explanation above, is: policy.

$\mathrm{H}_{1}$ : Profitability has a significant negative effect on debt

Firm size illustrates the magnitude of the company's operational activities. Firm size is often connected with the amount of assets owned by a company (Narita, 2012). Large companies are deemed to be safe if they obtain funding from external sources because they have a great deal of money. Our data illustrate the relationship between firm size and debt policies: when there is an increase in the size of the company, it is followed by an increase in the company's debt. Large companies often offer greater collateral guarantees (Haron, 2016). Based on the signaling theory, a large collateral guarantee can be a sign that a company is capable of repaying its external loans. Aside from that, large companies usually publish financial reports, which show information about their performance to external 
parties. This is in line with research conducted by Surya and Rahayuningsih (2012), Bernice et al., (2015), Haron (2016), and Nguyen et al. (2019) who showed that firm size has a positive effect on debt policy. The second hypothesis, based on the explanation above, is:

$\mathrm{H}_{2}$ : Firm size has a positive effect on debt policy.

Liquidity can be used to assess whether a company can fulfill its obligations. Obligations that can be fulfilled properly will reduce the number of outstanding obligations. Ghasemi and Razak (2016) and Kurniawan and Khafid (2016) interpreted liquidity as a company's ability to pay off its debts. Our provisional conjecture is that the trend in liquidity has decreased every year, and this has been followed by an increase in the level of debt. This illustrates the negative relationship of liquidity with debt. Based on the pecking order theory, when the level of retained earnings is high, then these funds can be used to finance the company's activities. These retained earnings can also be used to pay off corporate debts so that they can be reduced. Research conducted by Natasia and Wahidahwati (2015), and Haron (2016) showed that liquidity has a negative effect on debt policy. This happens as a result of the company being able to pay its debts, so the level of debt will reduce. However, Vijayakumaran and Vijayakumaran (2019) found that leverage has a positive effect on debt ratio. The third hypothesis, based on the explanation above, is:

\section{$\mathrm{H}_{3}$ : Liquidity has a negative effect on debt policy.}

Every decision taken by a company always has some risk attached to it. A company that is in financial difficulties faces a business risk. This can be due to uncertain conditions in the business environment, which may affect the company's profitability and income (Alnajjar, 2015). The trade-off theory considers the balance between the benefits and costs of certain actions, so that in determining the debt policy, we must consider the benefits against the cost of the debt plus the interest incurred, so that the company does not experience financial difficulties because of the excessive costs. The greater the business risks are, the lower the corporate debt will be, and vice versa (Haron, 2016). This happens because the increased level of debt will result in increased interest costs, which places a heavy burden on the company's finances and can cause financial difficulties. To avoid becoming bankrupt, the company must reduce its debt. The studies by Murtiningtyas (2012) and Haron (2016) both found that business risk has a negative influence on debt policy. The fourth hypothesis is:

$\mathrm{H}_{4}$ : Business risk has a significant negative effect on debt policy.
Investments can allow companies to develop, but to determine the correct level of investment, in the right form, requires careful consideration. The IOS is a decision about investments, in the form of the utilization of corporate assets, for investment choices that will affect the value of the company in the future (Giriati, 2016). According to Abor and Bokpin (2010), IOS as related to the current expenditure, the expected return, and value in the future as a result of the investment decision, has an impact on the value of the company. A company that invests successfully is a company that is well run, so that it is able to grow, and this is considered to be good by external parties. This can affect the company's share price so that the value of the company increases, because its value reflects its performance. Growing companies can increase their value so that they generate greater profits or earnings (Suryani \& Khafid, 2016). Improved performance will result in better profits or earnings, so that the earnings obtained can be used to finance the company's activities.

The explanation is in line with the pecking order theory about the order of funding, which is retained earnings, debt, and then stock issues. High corporate earnings result in high retained earnings, so that these can be used to fund the development of the company. When internal funds are sufficient, then the company will reduce its use of debt. However, when the IOS is low, it indicates that the company is not growing and internal funds are also low because of the reduced company profits. In this case, the best funding option is debt since debt is safer than a stock issue. The explanation is found in the research by Fitriyah and Hidayat (2011) who stated that the IOS negatively affects debt policy. Meanwhile, Panda and Nanda (2018) found that the relationship between investment opportunities and debt ratios was negative if using a sample of chemical firms, goods firms, food and agro, textile and transportation companies. In construction, machinery, and metal firm, the relationship between investment opportunities and debt ratio is positive. However, Nguyen et al., (2019) found that growth opportunities had a positive impact on structure capital. The fifth hypothesis, based on the explanation above, is:

$\mathrm{H}_{5}$ : The investment opportunity set has a significant negative effect on debt policy.

\section{Research Methods and Materials}

The population of this study consisted of 143 manufacturing companies listed on the Indonesian Stock Exchange (IDX). We observed the population for three years. The sample of the research was determined based on purposive sampling. The process of selecting the samples is shown in Table 1 below: 
Table 1: Research Samples' Selection Process

\begin{tabular}{|c|c|c|}
\hline Explanation & Beyond Criteria & Number \\
\hline Manufacturing companies listed on the IDX & & 143 \\
\hline $\begin{array}{l}\text { Manufacturing companies that have complete financial data to calculate variables in the } \\
\text { research during the study period. }\end{array}$ & $(28)$ & 115 \\
\hline $\begin{array}{l}\text { Manufacturing companies that issue financial statements that expire on December } 31 \text {, } \\
\text { during the study period. }\end{array}$ & $(2)$ & 113 \\
\hline Manufacturing companies that issue financial statements using the Indonesian rupiah. & $(27)$ & 86 \\
\hline $\begin{array}{l}\text { Manufacturing companies that made profits before tax, or experienced profits in the } \\
\text { year of observation. }\end{array}$ & $(28)$ & 58 \\
\hline Data Outlier & & $(16)$ \\
\hline Number of company samples & & 42 \\
\hline Period of observation & & 4 \\
\hline Number of analysis units & & 168 \\
\hline
\end{tabular}

Source: Secondary data processed 2020.

Table 2: Summary of Research Variable

\begin{tabular}{|l|l|l|}
\hline \multicolumn{1}{|c|}{ Variables } & \multicolumn{1}{|c|}{ Definition } & \multicolumn{1}{|c|}{ Measurement } \\
\hline $\begin{array}{l}\text { Debt Assets } \\
\text { Ratio }\end{array}$ & $\begin{array}{l}\text { One of the external funding sources used by a } \\
\text { company to finance its funding needs (Surya \& } \\
\text { Rahayuningsih, 2012) }\end{array}$ & $\begin{array}{l}\text { DAR= Total Asset } \\
\text { Total Debt } \\
\text { (Hartoyo et al., 2014; Mahardika et al., 2014) }\end{array}$ \\
\hline Profitability & $\begin{array}{l}\text { The ability of a company to generate profits or } \\
\text { earnings (Utama \& Khafid, 2015) }\end{array}$ & $\begin{array}{l}\text { ROA= Operating Profit } \\
\text { Total Asset } \\
\text { (Karina \& Khafid, 2015) }\end{array}$ \\
\hline Firm Size & $\begin{array}{l}\text { Amount of assets contained in a company } \\
\text { (Narita,2012) }\end{array}$ & $\begin{array}{l}\text { Ln. Total Asset } \\
\text { (Ng et al.,2012; Surya \& Rahayuningsih, 2012) }\end{array}$ \\
\hline Liquidity & $\begin{array}{l}\text { The ability of a company to pay off its debts } \\
\text { (Ghasemi \& Razak, 2016; Kurniawan \& Khafid, } \\
\text { 2016) }\end{array}$ & $\begin{array}{l}\text { CR= Current Assets } \\
\text { Current Liabilities } \\
\text { (Kurniawan \& Khafid, 2016) }\end{array}$ \\
\hline Business Risk & $\begin{array}{l}\text { Business risks occur because a company is } \\
\text { experiencing financial difficulties (Gómez et al., } \\
\text { 2015). }\end{array}$ & $\begin{array}{l}\text { ROIC= NOPAT } \\
\text { MODAL } \\
\text { (Brigham \& Houston, 2013) }\end{array}$ \\
\hline $\begin{array}{l}\text { Investment } \\
\text { Opportunity Set }\end{array}$ & $\begin{array}{l}\text { Decisions about investments, in the form of utilizing } \\
\text { the assets owned by a company that will have } \\
\text { an impact on the company's value in the future } \\
\text { (Giriati,2016) }\end{array}$ & $\begin{array}{l}\text { Market to Book Value Assets (MBVA) } \\
\text { = (Assets-Total Equity + (outstanding share sheet } \\
\text { x closing price)]: Total Assets } \\
\text { (Fitriyah \& Hidayat, 2011) }\end{array}$ \\
\hline
\end{tabular}

This study examined five independent variables that influenced the dependent variable. The dependent variable in this research was debt policy. The independent variables in this research were profitability, firm size, liquidity, business risk, and the investment opportunity set. The summary of the variables in this study can be seen in Table 2 below:

The data collection technique used the documentation technique. The data analysis technique used a multiple linear regression. This study also tested the classical assumption, which consisted of a normality test (Kolmogorof-Smirnov's test), multicollinearity test, autocorrelation test (runs test), and a heteroscedasticity test (glacial test). This study uses the multiple linear regression equation as follows:

$\mathrm{DAR}=\alpha-\beta 1 \mathrm{PROF}+\beta 2 \mathrm{UKU}-\beta 3 \mathrm{LIK}-\beta 4 \mathrm{RISK}-\beta 5 \mathrm{SKI}+\mathrm{e}$

Where:

$\mathrm{DAR}=$ Debt Policy

PROF $=$ Profitability

$\mathrm{UKU}=$ Firm Size 
Hasan MUKHIBAD, Subowo SUBOWO, Denis Opi MAHARIN, Saparuddin MUKHTAR /

Journal of Asian Finance, Economics and Business Vol 7 No 6 (2020) 029 - 037

LIK = Liquidity

RISK $=$ Business Risk

SKI = Investment Opportunity Set

\section{Results}

Table 3 shows the results of the descriptive test on the variables. The results indicate that debt policy has a minimum value of 0.131 , a maximum value of 0.994 , a mean of 0.42283 and a standard deviation of 0.177836 . The level of profitability has a minimum value of 0.026 , a maximum of 0.655 , a mean of 0.15489 , and a standard deviation of 0.102058 . Firm size has a minimum value of 11.109 , a maximum of 13.963 , a mean of 12.25290 , and a standard deviation of 0.694760 . Liquidity has a minimum value of 0.957 , a maximum of 8.089 , a mean of 2.42643, and a standard deviation of 1.383740. Business risk has a minimum value of 0.011 , a maximum of 0.513 , a mean of 0.16201 , and a standard deviation of 0.94673 .

The results of the model's feasibility test (or the classical assumption test) included tests for normality, multicollinearity, autocorrelation, and heteroscedasticity. The result of the normality test shows a Sig. value of $0.097>0.05$, which means that there is no data normality problem. The results of the multicollinearity test show a VIF value for the profitability variable of 1.690 , a VIF value for the firm size variable of 1.061, a VIF value for the liquidity variable of 1.035 , a VIF value for the business value variable of 1,855 , and a VIF value for the IOS variable of 1.539. All five variables have VIF values of less than 10. It can be concluded that there is no multicollinearity problem.

The results of the autocorrelation test show a significance value of more than 0.05 (0.089) and indicate there is no autocorrelation problem. The results of the heteroscedasticity test show significant values for profitability of 0.264 , for firm size of 0.709 , for liquidity of 0.246 , for the business variable of 0.105 , and for the IOS of 0.429 . The five variables also produced a significant value of more than 0.05 and, hence, the conclusion is that there is no problem with heteroscedasticity. Based on the results of this test, we conclude that all the data did not have the classical problems.

\section{Discussion}

The hypothesis that profitability has a significant negative effect on debt policy is rejected. The researchers assume this is due to the companies making additional debt repayments, without paying attention to, or taking into account, their profitability. This can be seen in PT. Indocement Tunggal Prakasa Tbk., which declared a profit of $25.8 \%$ in 2012, that decreased to $22.8 \%$ in 2013 , fell again to $20.8 \%$ in 2014 , and experienced a further decline in 2015 to $18.3 \%$. Whereas its level of debt in 2012 was $14.7 \%$, this experienced a decrease in 2013 to $14.5 \%$, in 2014 it rose to $14.9 \%$, and in 2015 it experienced a decline to $13.6 \%$. PT. Darya Varia Laboratoria Tbk., had a profit of $18.3 \%$ in 2012 , this decreased in 2013 to $14 \%$, in 2014 it dropped to $7.7 \%$, but experienced an increase in 2015 to $9.2 \%$. Whereas the level of debt in 2012 amounted to $21.7 \%$, this grew to $24.8 \%$ in 2013 ; in 2014 , it fell to $23.7 \%$ and in 2015 experienced an increase to $29.3 \%$. The results of this study support research conducted by Narita (2012) that shows that profitability has no effect on debt policy. The same findings are also shown by Liu and Ren, (2005) and Mahmud, (2003)industry class, and firmspecific factors in three Asian countries, Japan, Malaysia, and Pakistan. Firm-specific factor studies include firm's growth, size, assets composition, profitability, operating leverage, and dividends. The study covers a period of 10 years (1989-1998 who found that a company's profitability does not have an influence on its capital structure. There are indications that companies in Indonesia do not use profitability indicators when determining whether they still need to reduce their level of debt.

The research results also found that firm size does not have a positive effect on debt policy. The result of this study is in line with the research results of Narita (2012), and Sofat and Singh (2017), which showed that company measures have no effect on debt policy. This finding also concludes that companies do not have a tendency to increase or reduce their level of debt. From the point of view of potential creditors, the size of the company is not a factor in their decision to offer credit or not. This can be seen in PT. Ultrajaya Milk Industry and Trading Company Tbk., which had a firm size of $12.38 \%$ in 2012, experienced an increase in 2013 to $12.45 \%$. In 2014 , it rose to $12.47 \%$, and then experienced

Table 3: Descriptive Analysis

\begin{tabular}{|l|c|c|c|c|c|c|}
\hline \multicolumn{1}{|c|}{ Description } & DAR & ROA & Ln Size & Liquidity & Risk & IOS \\
\hline Average & 0.423 & 0.155 & 12.253 & 2.426 & 0.162 & 1.674 \\
\hline Minimal & 0.131 & 0.026 & 11.109 & 0.957 & 0.011 & 0.201 \\
\hline Maximum & 0.994 & 0.655 & 13.963 & 8.089 & 0.513 & 5.634 \\
\hline St. Dev & 0.178 & 0.102 & 0.695 & 1.384 & 0.094 & 1.147 \\
\hline
\end{tabular}


a further increase in 2015 to $12.55 \%$. Whereas its level of debt was $30.7 \%$ in 2012 , it experienced a decrease in 2013 to $28.1 \%$. In 2014 it experienced another decline to $22.1 \%$ and in 2015 it dropped to $21 \%$. PT. Argha Karya Prima Industry Tbk., increased in size in 2012 to $12.23 \%$, in 2013 it grew to $12.32 \%$, in 2014 to $12.35 \%$, and in 2015 to $12.46 \%$. Whereas the level of debt in 2012 was $50.8 \%$, this dropped to $50.6 \%$ in 2013 , in 2014 it rose to $53.5 \%$ and in 2015 experienced an increase to $61.6 \%$.

Table 4 shows that liquidity has a negative effect on debt policy. Liquid companies are companies that are capable of meeting their obligations. Liquidity is the ability of a company to pay its debts (Kurniawan \& Khafid, 2016). Based on the pecking order theory, a company that has increased its liquidity has increased its ability to pay its debts, and thus reduce the level of its debt. This is due to the company being able to meet its need for funds from its retained earnings and to meet its debt repayments. The results of this research support the research conducted by Natasia and Wahidahwati (2015) and Haron (2016) who found that liquidity has a negative effect on debt policy. However, these findings reject Tailab (2014) and Mahmud (2003)industry class, and firmspecific factors in three Asian countries, Japan, Malaysia, and Pakistan. Firm-specific factor studies include firm's growth, size, assets composition, profitability, operating leverage, and dividends. The study covers a period of 10 years (1989-1998, who believed that liquidity had a positive effect on debt.

The results of this study also found that the business risk has no negative effect on debt policy. The business risk occurs because the company is experiencing financial difficulties (Gómez et al., 2015). The researchers assume the fourth hypothesis is rejected because companies change their views of risk; it is usually associated with negative aspects that are thought to be disadvantageous or uncertain, but there may be positive opportunities that could bring benefits to the companies (Gitosudarmo \& Basri, 2014). Gitosudarmo and Basri (2014) thought that companies, which could anticipate uncertainty in the future, would make maximum use of it because the inherent risk in dividing wealth into that which may be consumed and that which will be invested is expected to result in an increase in wealth in the future. When the level of business risk is high, it raises the level of debt and when the business risk is low, then follows a decrease in the level of debt.

This can be seen in PT. Sekar Laut Tbk., which had a business risk level of 0.062 in 2012; it experienced an increase to 0.082 in 2013, in 2014 it experienced another increase to 0.110 , and in 2015 it experienced a further increase to 0.132 . The level of debt in 2013 amounted to 0.482 , which experienced an increase in 2013 to 0.564 , and in 2014 experienced a further increase to 0.592 , and in 2015 it increased again to 0.597. PT Nusantara Inti Corpora Tbk. had a business risk level of 0.147 in 2012, it experienced an increase in 2013 to 0.345 . During 2014 this decreased to 0.146 and it experienced an increase to 0.159 in 2015. The debt in 2012 was 0.367 , which experienced an increase in 2013 to 0.475 . In 2014, it decreased to 0.450 and experienced an increase in 2015 to 0.475 . The result of this study is aligned with the research conducted by Surya and Rahayuningsih (2012), and Sofat and Singh (2017), who all stated that business risk does not have an influence on debt policy.

The last indicator that we used to influence the debt policy was the IOS. This study found that the IOS has a significant negative effect on debt policy. Giriati (2016) stated that the IOS is an opportunity or chance for a company to invest so that it will provide benefits in the future. In line with the pecking order theory, the choices of funding for the company are first retained earnings, second is debt, then a share issue. When the amount of its internal funds is sufficient to enable the company to finance its activities, then the company prefers to use those funds, rather than take on extra debt. However, if the IOS rate is low, then the company can be said to have experienced little growth. Low growth is believed to be the first sign of a decline in company earnings (Suryani \& Khafid, 2016). This can result in a decrease in the company's retained earnings, and an increase in the company's debt.

As happened with PT. Sekar Bumi, Tbk., which had an investment opportunity set (IOS) of 1.707 in 2012, it experienced a decrease in 2013 to 1.431 . In 2014, it rose to 1.920 and in 2015 experienced a decline to 1.705 . The level of

Table 4: Hypothesis Test

\begin{tabular}{|l|c|c|c|c|c|}
\hline \multicolumn{1}{|c|}{ Model } & & & Sig & Hypothesis \\
\hline Profitability & Negative & $\rightarrow$ Debt & -0.180 & 0.122 & $\mathrm{H}_{1}$ rejected \\
\hline Size & Positive & $\rightarrow$ Debt & 0.007 & 0.594 & $\mathrm{H}_{2}$ rejected \\
\hline Liquidity & Negative & $\rightarrow$ Debt & $-0.093^{* * *}$ & 0.000 & $\mathrm{H}_{3}$ accepted \\
\hline Business Risk & Negative & $\rightarrow$ Debt & 0.034 & 0.796 & $\mathrm{H}_{4}$ rejected \\
\hline IOS & Negative & $\rightarrow$ Debt & $-0.030^{* * *}$ & 0.000 & $\mathrm{H}_{5}$ accepted \\
\hline
\end{tabular}

*** Significant at $1 \%$ 
debt in 2012 was 0.558 , this experienced an increase in 2013 to 0.615 . In 2014, it fell to 0.529 , and in 2015 it experienced an increase to 0.548. PT. Kedaung Setia Industrial, Tbk., had an IOS of 5.933 in 2012, experienced a decline in 2013 to 5.27. In 2014, it dropped to 0.691 , and it experienced a further decline to 0.560 in 2015 . The debt level in 2012 was 0.446 , it experienced an increase in 2013 to 0.609 . In 2014 it rose to 0.613 , and in 2015 it experienced another increase to 0.781 . The result of this study is in line with Fitriyah and Hidayat (2011) who showed the investment opportunity set has a negative influence on debt policy.

\section{Conclusions}

This study focuses on the factors that influence debt policies. We use liquidity, the investment opportunity set, profitability, and firm size to explain debt policies. Our study finds that corporate debt policies in Indonesia are negatively affected by liquidity and the investment opportunity set. Moreover, this research shows that debt policies are not affected by profitability or firm size. This research only uses limited variables, but our sample covers all the public companies in Indonesia. Thus, our weakness is ignoring corporate governance and economic conditions as variables that may affect the debt policies as suggested by Vijayakumaran \& Vijayakumaran (2019). We suggest further research to identify the factors of corporate governance and economic conditions in explaining debt policies in Indonesia.

\section{References}

Abdullah, N., \& Pok, W. C. (2015). Separation of Cash Flow Rights and Control Rights and Debt. Journal of Accounting in Emerging Economies, 5(2), 184-201. https://doi.org/10.1108/JAEE-09-2011-0030

Abor, J., \& Bokpin, G. A. (2010). Investment Opportunities , Corporate Finance, and Dividend Payout Policy. Studies in Economics and Finance, 27(3), 180-194. https://doi.org/10.1108/10867371011060018

Alnajjar, M. I. M. (2015). Business Risk Impact on Capital Structure : A Case of Jordan Industrial Sector. Global Journal of Management and Business Research: C Finance, 15(1), 1-9.

Bernice, Y., Nugrahanti, Y. W., \& Mahastanti, L. A. (2015). The Impact of Managerial Ownership, Institutional Ownership and Company Size towards Debt Policy. The 3rd IBEA International Conference on Business, Economics and Accounting.

Bokpin, G. A. (2009). Macroeconomic development and capital structure decisions of firms: Evidence from emerging market economies. Studies in Economics and Finance, 26(2), 129142. https://doi.org/10.1108/10867370910963055

Brigham, E. F., \& Houston, J. F. (2013). Dasar-Dasar Manajemen Keuangan. Jakarta: Salemba Empat.
Buvanendra, S., Sridharan, P., \& Thiyagarajan, S. (2016). Role of country-specific factors on capital structure decision - evidence from Sri Lankan listed firms. Global Business Review, 17(3), 582-593. https://doi.org/10.1177/0972150916630454

Dalbor, M. C., \& Upneja, A. (2004). The Investment Opportunity Set and the Long-Term Debt Decision of U.S. Lodging Firms. Journal of Hospitality and Tourism Research, 28(3), 346-355. https://doi.org/10.1177/1096348004265024

Desmintari, \& Yetty, F. (2015). Effect of Profitability, Liquidity and Assets Structure on The Company Debt Policy. International Journal of Business and Commerce, 5(06), 117-131.

Fitriyah, F. K., \& Hidayat, D. (2011). Pengaruh Kepemilikan Institusional, Set Kesempatan Investasi dan Arus Kas Bebas Terhadap Utang. Media Riset Akuntansi, 1(1), 31-76.

Gajurel, D. P. (2011). Capital Structure Management in Nepalese Enterprises. SSRN Electronic Journal, (2005), 0-108. https:// doi.org/10.2139/ssrn.778106

Ghasemi, M., \& Razak, N. H. A. (2016). The Impact of Liquidity on The Capital Structure : Evidence From Malaysia. International Journal of Economics and Finance, 8(10), 130-139. https:// doi.org/10.5539/ijef.v8n10p130

Giriati. (2016). Free Cash Flow, Dividend Policy, Investment Opportunity Set, Opportunistic Behavior and Firm's Value. Procedia-Social and Behavioral Sciences, 21(9), 248-254. https://doi.org/10.1016/j.sbspro.2016.05.013

Gitosudarmo, H. I., \& Basri, H. (2014). Manajemen Keuangan. Yogyakarta: BPFE.

Gómez, G., Rivas, A. M., \& Bolaños, E. R. L. (2015). The Determinants of Capital Structure in Peru. Academia Revista Latinoamericana de Administracion, 27(3), 341-354. https:// doi.org/10.1108/ARLA-01-2014-0007

Handriani, E., \& Robiyanto, R. (2018). Investment opportunity and industrial growth in Indonesia. International Journal of Business and Society, 19(2), 295-312.

Haron, R. (2016). Do Indonesian Firms Practice Target Capital Structure? A Dynamic Approach. Journal Of Asia Business Studies, 10(3), 318-334. https://doi.org/10.1108/JABS-072015-0100

Hartoyo, A. K. W., Khafid, M., \& Agustina, L. (2014). FaktorFaktor yang Mempengaruhi Struktur Modal Perusahaan Tekstil dan Garmen di BEI. Accounting Analysis Journal, 3(2), 247254.

Hikmah, K., Haryono, T., Djuminah, \& Nasrulloh, R. S. (2019). Investment opportunity set, institutional ownership, family ownership and funding policy. Management Science Letters, 9(Special Issue 13), 2201-2214. https://doi.org/10.5267/j.msl.2019.7.032

Jóźwiak, B. K., Marszalek, J., \& Sekula, P. (2015). Determinants of Debt-Equity Choice - Evidence From Poland. Emerging Markets Journal, 5(2), 0-8. https://doi.org/10.5195/emaj.2015.66 
Karina, F., \& Khafid, M. (2015). Determinan Profitabilitas pada Perusahaan Properti dan Real Estate Go Public di Indonesia. Jurnal Dinamika Akuntansi, 7(1), 1-9.

Kurniawan, A. R., \& Khafid, M. (2016). Factors Affecting The Qualityy of Profit in Indonesia Banking Companies. Jurnal Dinamika Akuntansi, 8(1), 30-38.

Kyissima, K. H., Xue, G. Z., \& Abeid, A. R. (2019). Analysis of capital structure stability of listed firms in China. China Finance Review International, 2044-1398. https://doi.org/10.1108/ CFRI-05-2018-0044

Liu, Y., \& Ren, J. (2005). An Empirical Analysis on the Capital Structure of Chinese Listed IT Companies. International Journal of Business and Management, 4(8), 46-51.

Mahardika, E. S. S., Khafid, M., \& Agustina, L. (2014). Pengaruh Struktur Kepemilikan, Ukuran dan Umur Peusahaan Terhadap Kinerja Intellectual Capital. Accounting Analysis Journal, 3(1), 100-108.

Mahmud, M. (2003). The relationship between economic growth and capital structure of listed companies: Evidence of Japan, Malaysia, and Pakistan. Pakistan Development Review, $42(4$ II), 727-748. https://doi.org/10.30541/v42i4iipp.727-750

Marfuah. (2014). Pengaruh Investment Opportunity Set dan Ukuran Perusahaan Terhadap Hubungan Antara Free Cash Flow Dengan Kebijakan Hutang. Aplikasi Bisnis, 15(9), 1823-1825.

Maulana, H. (2017). Ada 19 perusahaan bersiap terbitkan obligasi. Kontan.Co.Id, p. 1. Retrieved from https://investasi.kontan. co.id/news/ada-19-perusahaan-bersiap-terbitkan-obligasi

Murtiningtyas, A. I. (2012). Pengauh Kebijakan Dividen, Kepemilikan Manajerial, Kepemilikan Institusional, Profitabilitas, dan Risiko Bisnis Terhadap Kebijakan Hutang. Accounting Analysis Journal, 1(2), 1-6.

Narita, R. M. (2012). Analisis Kebijakan Hutang. Accounting Analysis Journal, 1(2), 1-6.

Natasia, W., \& Wahidahwati. (2015). Faktor-Faktor yang Mempengaruhi Kebijakan Hutang Perusahaan yang Terdapat di Bursa Efek Indonesia. Jurnal Ilmu \& Riset Akuntansi, 4(12), $1-22$.

Ng, T. H., Chong, L. L., \& Ismail, H. (2012). Firm Size and Risk Taking in Malaysia's Insurance Industry. Yhe Journal of Risk Finance, 14(1), 71-86. https://doi.org/10.1108/JRF-11-20120079

Nguyen, C. T., Bui, C. M., \& Pham, T. D. (2019). Corporate capital structure adjustments: Evidence from Vietnam stock exchange market. Journal of Asian Finance, Economics and Business, 6(3), 41-53. https://doi.org/10.13106/jafeb.2019.vol6.no3.41

Nguyen, H. T., \& Nguyen, A. H. (2020). The Impact of Capital Structure on Firm Performance: Evidence from Vietnam. Journal of Asian Finance, Economics and Business, 7(4), 97105. https://doi.org/10.13106/jafeb.2020.vol7.no4.97

Osmorsa. (2019, September). Hati-hati! Risiko Indonesia Gagal Bayar Utang Meningkat - Detik Finance. Osmorsa.Com, 1.
Retrieved from https://osmorsa.com/bisnis/176816/hati-hatirisiko-indonesia-gagal-bayar-utang-meningkat-detikfinance/

Panda, A. K., \& Nanda, S. (2018). Determinants of capital structure; a sector-level analysis for Indian manufacturing firms. International Journal of Productivity and Performance Management, 1741-0401. https://doi.org/10.1108/IJPPM-12-2018-0451

Purwohandoko. (2017). The Influence of Firm 's Size , Growth , and Profitability on Firm Value with Capital Structure as the Mediator: A Study on the Agricultural Firms Listed in the Indonesian Stock Exchange. International Journal of Economics and Finance, 9(8), 103-110. https://doi.org/10.5539/ijef.v9n8p103

Qayyum, N., \& Noreen, U. (2019). Impact of capital structure on profitability: A comparative study of islamic and conventional banks of Pakistan. Journal of Asian Finance, Economics and Business, 6(4), 65-74. https://doi.org/10.13106/jafeb.2019.vol6.no4.65

Rodrigues, S. V., de Moura, H. J., Santos, D. F. L., \& Sobreiro, V. A. (2017). Capital structure management differences in Latin American and US firms after 2008 crisis. Journal of Economics, Finance and Administrative Science, 22(42), 51-74. https://doi.org/10.1108/JEFAS-01-2017-0008

Salehi, M., Lotfi, A., \& Farhangdoust, S. (2017). The Effect of Financial Distress Costs on Ownership Structure and Debt Policy. Journal of Management Developmet, 36(10), 12161229. https://doi.org/10.1108/JMD-01-2017-0029

Serghiescu, L., \& Vaidean, V.-L. (2014). Determinant factors of the capital structure of a firm- an empirical analysis. Emerging Markets Queries in Finance and Business, 15(14), 1447-1457. https://doi.org/10.1016/S2212-5671(14)00610-8

Skinner, D. J. (1993). The investment opportunity set and accounting procedure choice. Preliminary evidence. Journal of Accounting and Economics, 16(4), 407-445. https://doi.org/10.1016/01654101(93)90034-D

Sofat, R., \& Singh, S. (2017). Determinants of Capital Structure: an Empirical Study of Manufacturing Firms in India. International Journal of Law and Management, 59(6), 1029-1045. https://doi.org/10.1108/IJLMA-05-2016-0051

Sugianto, D. (2019, July 25). Deretan Perusahaan RI yang Gagal Bayar Utang. Detikfinance, p. 1. Retrieved from https:// finance.detik.com/berita-ekonomi-bisnis/d-4639386/deretanperusahaan-ri-yang-gagal-bayar-utang/3

Surya, D., \& Rahayuningsih, D. A. (2012). Faktor-Faktor yang Mempengaruhi Keuangan yang Terdaftar dalam Bursa Efek Indonesia. Jurnal Bisnis Dan Akuntansi, 14(3), 213-225.

Suryani, A. D., \& Khafid, M. (2016). Analisis Faktor-Faktor yang Mempengaruhi Kebijakan Hutang. Accounting Analysis Journal, 5(2), 95-103.

Tailab, M. M. K. (2014). The Effect of Capital Structure on Profitability of Energy American Firms : International Journal of Business and Management Invention, 3(12), 2319-801x. 
Utama, P., \& Khafid, M. (2015). Faktor-Faktor yang Mempengaruhi Luas Pengungkapan Modal Intelektual pada Perusahaan Perbankan di BEI. Accounting Analysis Journal, 4(2), 1-10.

Vătavu, S. (2015). The Impact of Capital Structure on Financial Performance in Romanian Listed Companies. Emerging Markets Queries in Finance and Business, 32(15), 1314-1322. https://doi.org/10.1016/S2212-5671(15)01508-7

Vijayakumaran, R., \& Vijayakumaran, S. (2019). Leverage, Debt Maturity and Corporate Governance: Evidence From Chinese Listed Companies. Asian Economic and Financial Review, 9(4), 491-506. https://doi.org/10.18488/journal. aefr.2019.94.491.506
Vijayakumaran, S., \& Vijayakumaran, R. (2019). Corporate governance and capital structure decisions: Evidence from Chinese listed companies. Journal of Asian Finance, Economics and Business, 6(3), 67-79. https://doi.org/10.13106/jafeb.2019. vol6.no3.67

Wareza, M. (2018, August 8). Tujuh Perusahaan akan Terbitkan Obligasi Senilai Rp 13,76 T. CNBC Indonesia, p. 1. Retrieved from https://www.cnbcindonesia.com/ market/20180808193516-17-27646/tujuh-perusahaan-akanterbitkan-obligasi-senilai-rp-1376-t 